\title{
Introduction to the special issue on polar night studies conducted onboard RV Helmer Hanssen in the Svalbard area
}

\author{
Ole Jørgen Lønne • Stig Falk-Petersen • \\ Jørgen Berge
}

Received: 23 October 2014/Revised: 28 October 2014/ Accepted: 28 October 2014/Published online: 5 November 2014 (C) The Author(s) 2014. This article is published with open access at Springerlink.com

\section{Introduction}

Polar night studies at high latitudes have during the last years become a major research focus for ARCTOS researchers, spearheaded by research cruises lead by UiT and $\mathrm{MSc} / \mathrm{PhD}$ courses lead by UNIS. During the last 4 years, the RV Helmer Hanssen have been assigned to conduct research well into the nautical polar night (Berge et al. in press), a temporal and spatial part of the Arctic Ocean that until now have remained more or less unstudied.

For a long time, ice-covered areas of the Arctic were presumed to be unproductive and early scientific studies in the Arctic generally supported this paradigm (Nansen 1902). Evidence of human settlements in the high Arctic over several thousand years, however, conflicted with these early observations and constituted a paradox as to how human populations could subsist in regions considered to be biological deserts. Further investigations revealed the existence of productivity hot spots on par with some of the most productive places on earth and provided the first indications of complexity and the importance of the links

This article belongs to the special Polar Night issue, coordinated by Ole Jørgen Lønne.

O. J. Lønne $(\bowtie) \cdot$ J. Berge

University Centre in Svalbard, POB 156, 9171 Longyearbyen, Norway

e-mail: ole.jorgen.lonne@unis.no

S. Falk-Petersen · J. Berge

Faculty of Biosciences, Fisheries and Economics,

University of Troms $\varnothing$, 9037 Tromsö, Norway

S. Falk-Petersen

Akvaplan-niva, Fram Centre, 9296 Tromsö, Norway between ice, ocean, and land in Arctic ecosystems. During the last 20 years, culminating with the third International Polar Year (IPY 2007-2009), however, national and international research efforts in the Arctic have sharply increased. This increase in attention and research efforts are paralleled by an increased awareness of both the fisheries and petroleum resources available at high latitudes as well as new shipping routes emerging following a reduction of the Arctic ice cover (see e.g. Barber et al. in press). Despite the fact that attention, awareness and research efforts have increased, there are still major and fundamental gaps in knowledge, preventing a holistic understanding of the Arctic as a single, linked system undergoing unprecedented change and in an earth science perspective. Perhaps the most obvious and largest of these known gaps is centred around the widely accepted paradigm that Arctic marine ecosystems are best compared with a marine desert during the long and dark polar night. Just as the paradigm of the Arctic Ocean being an unproductive biotope was refuted a hundred years ago, the prevailing view of the polar night as devoid of biological activity has recently been challenged (Berge et al. in press for a review).

\section{Highlights and outlook}

Here we report on a diverse set of biological studies, all conducted onboard the RV Helmer Hanssen in January 2012 and 2013, reporting on various aspects of polar night biology (Fig. 1). This special issue can roughly be divided into three categories: (1) studies with light as the main theme, including solar, lunar, and biologically produced light; Johnsen et al. (2014) on bioluminescence, Webster et al. (2013) on influence of moon on nekton, Morata, and Soreide (2013) on effect of light on Calanus spp., and 


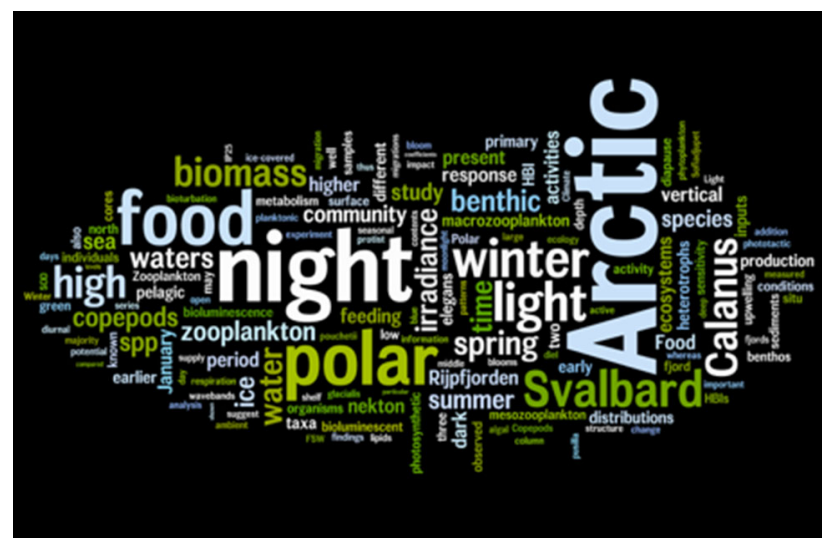

Fig. 1 Word cloud highlighting the most common used words in the titles and keywords of all the 10 papers included in this special issue. The size of the word reflect how many times they are occurring in titles, abstracts, and keywords

Båtnes et al. (2013) on detection limits of light in Calanus spp.; (2) Process studies on linkages between pelagic/ sympagic and benthos, including biomarker indicators: Morata et al. (2013) on benthic activities, Brown et al. (2013) on biomarkers, Falk-Petersen et al. (2014) on upwelling processes assumed to fuel biological production regimes; (3) Pelagic communities and biology: Grigor et al. (2014) on chaetognaths, Vader et al. (2014) on phototrophs, and Blachowiach-Samolyk et al. (2014) on mesozooplankton communities.

In combination, these ten papers represent a major increase in our general knowledge, concerning biological patterns and processes characteristic of the polar night. Also, and equally important, all ten papers are directly based upon two relatively short (10 days) scientific cruises north of Svalbard in January 2012 and 2013. The fact that these ten papers, in addition to other papers published elsewhere (Berge et al. 2012; Kraft et al. 2012; Daase et al. 2014) are all direct outcomes of two such short cruises, illustrate the fact that the polar night at high latitude constitute one major gap in current knowledge. The magnitude of this gap has only recently have become evident (see Berge et al. in press for a review). Herein, we present ten dedicated and focused studies on different aspects of polar night ecology and biological oceanography (see Fig. 1). Results include studies on the small green alga Micromonas pusilla and the haptophyte Phaeocystis pouchetiitwo key phototrophs in the Arctic, commonly blooming during the arctic spring and summer. As was expected, chlorophyll concentrations were very low during our study period and across our study area $\left(78^{\circ}-81^{\circ} \mathrm{N}\right)$. Vader et al. (2014) showed, using a molecular approach, that $M$. pusilla and $P$. pouchetii are widely distributed in Svalbard waters also at the height of the polar night. Both species were detected in pelagic samples from both fjords and the open ocean, ice-covered and ice-free locations, shallow and deep water and from Atlantic, Arctic, and Coastal water masses. The presence of these phytoplankton species shows that overwintering cells are present and ready to bloom as soon as the sun returns in late March. In a different study, Błachowiak-Samołyk et al. (2014) showed that a large part of the herbivorous community had already stared to migrate into the upper water layers, both in Rijpfjorden and the Fram Strait. This upward migration occured 2 months before the return of the sunlight and onset of the primary production. In another study, Falk-Petersen et al. (2014) were able to relate the absence of ice and prevailing wind directions with a pronounced upwelling along the continental slope North of Svalbard. This upwelling event, driven by the combination of little ice and easterly winds, is hypothesised to create a similar condition to those that once supported the large stocks of bowhead whales before they were hunted to near extinction in the late 1700s (FalkPetersen et al. 2014).

The three papers highlighted here (section above) represent only three out of ten papers, and only three out several topics, all centred around polar night in the Arctic. As is evident from the summary of all titles and keywords (Fig. 1), there is a general focus on "light" and "food" among the studies-both "topics" generally considered to be limited during the polar night. Polar marine ecosystem processes, as in all other ecosystems, are direct consequences of the complex behaviours and interactions between organisms, many of which are driven by the physical environment. Accordingly, a classical paradigm in Arctic marine ecology suggests that most biological processes stop during the polar night at high latitudes due to low food availability and the lack of light (Smetacek and Nicol 2005; Piepenburg 2005). Recently, this assumption was challenged by presenting evidence of diel vertical migration (DVM) of zooplankton during the polar night (Berge et al. 2009). This discovery initiated a large range of diverse studies, most presenting unexpected new discoveries of a system in full operation and with high activity levels. The results presented in this volume is a natural extension of the work published so far on polar night ecology and is an important contribution towards our general understanding of the Arctic marine system. Not the least, and based on the findings both included in this volume and previous reports (see Berge et al. in press for a review), the current reduction of Arctic sea ice is likely to have both a direct and indirect impact on marine organisms, their interactions, and ultimately ecosystem processes. But without a more fundamental perception of Arctic ecosystem function, such impacts will remain largely impossible to understand and predict. Winter ecology of Arctic marine systems, then, is a largely new field of 
science with the potential for radically altering our fundamental perception of basic Arctic ecosystems processes, current state of the ecosystem and connections between the biosphere, hydrosphere and cryosphere within the Polar Region. To this end, this volume and the ten papers included are important and significant steps towards a more holistic and general understanding of the Arctic marine ecosystem.

Acknowledgments We would like to thank all the reviewers on the individual manuscripts that together make up this special issue. Thanks to them and their constructive suggestions it is possible to publish this rather unique collection of information on polar night ecology. Moreover, we gratefully acknowledge the input and team effort from all the participants of the two polar night cruises in 2012 and 2013, and for their willingness to publish their results in this special issue. Last but not least, we thank the editor in chief of Polar Biology Dieter Piepenburg, and his team, for the help and guidance needed to put this collection of manuscripts together. This special issue is a contribution to the Marine Night project (project number 226417) funded by the Norwegian Research Council.

Open Access This article is distributed under the terms of the Creative Commons Attribution License which permits any use, distribution, and reproduction in any medium, provided the original author(s) and the source are credited.

\section{References}

Barber DG, Hop H, Mundy CJ, Else B, Dmitrenko IA, Tremblay J-E, Ehn JK, Assmy P, Daase M, Candlish LM (in press) Selected physical, biological and biogeochemical implications of a rapidly changing Arctic Marginal Ice Zone. Progress in Oceanography

Båtnes AS, Miljeteig C, Berge J, Greenacre M, Johnsen G (2013) Quantifying the light sensitivity of Calanus spp. during the polar night: potential for orchestrated migrations conducted by ambient light from the sun, moon, or aurora borealis? Polar. doi:10. 1007/s00300-013-1415-4

Berge J, Cottier FR, Last KS et al. (2009) Diel vertical migration of Arctic zooplankton during the polar night. Biol Lett 5:69-72. doi:10.1098/rsbl.2008.0484

Berge J, Varpe O, Moline MA, Wold A, Renaud PE, Daase M, FalkPetersen S (2012) Retention of ice-associated amphipods: possible consequences for an ice-free Arctic Ocean. Biol Lett 8(6):1012-1015. doi:10.1098/rsbl.2012.0517

Berge J, Renaud PE, Darnis G, Cottier F, Last K, Gabrielsen TM, Johnsen G, Seuthe L, Weslawski JM, Leu E, Moline M,
Nahrgang J, Søreide JE, Varpe $\varnothing$, Lønne OJ, Daase M, FalkPetersen S (in press) In the dark: paradigms of Arctic ecosystems during polar night challenged by new understanding. Progress in Oceanography

Brown TA, Hegseth EN, Belt ST (2013) A biomarker-based investigation of the mid-winter ecosystem in Rijpfjorden. Polar Biology, Svalbard. doi:10.1007/s00300-013-1352-2

Blachowiach-Samolyk K, Wiktor JM, Hegseth EN, Wold A, FalkPetersen S Kubiszyn AM (2014) Winter Tales-the dark side of planktonic life

Daase M, Varpe O, Falk-Petersen S (2014) Non-consumptive mortality in copepods: occurrence of Calanus spp. carcasses in the Arctic Ocean during winter. J Plankton Res 36(1):129-144. doi:10.1093/plankt/fbt079

Falk-Petersen S, Pavlov V, Berge J, Cottier F, Kovacs KM, Lydersen C (2014) At the rainbow's end: high productivity fueled by winter upwelling along an Arctic shelf. Polar Biol. doi:10.1007/ s00300-014-1482-1

Grigor JJ, Marais A, Falk-Petersen S, Varpe $\varnothing$ (2014) Polar night ecology of a pelagic predator, the chaetognath Parasagitta elegans

Johnsen G, Candeloro M, Berge J, Moline M (2014) Glowing in the dark: discriminating patterns of bioluminescence from different taxa during the Arctic polar night. Polar Biol 37(5):707-713. doi:10.1007/s00300-014-1471-4

Kraft A, Berge J, Varpe Ø, Falk-Petersen S (2012) Feeding in Arctic darkness: mid-winter diet of the pelagic amphipods Themisto abyssorum and T. libellula. Mar Biol 160(1):241-248. doi:10. 1007/s00227-012-2065-8

Morata N, Soreide JE (2013) Effect of light and food on the metabolism of the Arctic copepod Calanus glacialis. Polar Biol. doi:10.1007/s00300-013-1417-2

Morata N, Michaud E, Włodarska-Kowalczuk M (2013) Impact of early food input on the Arctic benthos activities during the polar night. Polar Biol. doi:10.1007/s00300-013-1414-5

Nansen F (1902) Norwegian North Polar Expedition 1893-1896, Scientific Results Vol 3: The Oceanography of the North Pole Basin. Longmans, Green, Toronto, Canada

Piepenburg D (2005) Recent research on Arctic benthos: common notions need to be revised. Polar Biol 28:733-755. doi:10.1007/ s00300-005-0013-5

Smetacek V, Nicol S (2005) Polar ocean ecosystems in a changing world. Nature 437:362-368. doi:10.1038/nature04161

Vader A, Marquardt M, Meshram AR, Gabrielsen T (2014). Key Arctic phototrophs are widespread in the polar night

Webster CN, Varpe Ø, Falk-Petersen S, Berge J, Stübner E, Brierley AS (2013) Moonlit swimming: vertical distributions of macrozooplankton and nekton during the polar night. Polar Biol. doi:10.1007/s00300-013-1422-5 